Research.

\title{
ANALYSIS OF BALANCED SCORECARD PERSPECTIVE IN PRIVATE COLLEGE MANAGEMENT AS A BASIC OF LECTURER PERFORMANCE ASSESMENT (Case Study of Computer Science College of Binaniaga)
}

\author{
Ismulyana Djan \\ Computer Sciience College of Binaniaga, Bogor, Indonesia \\ ismulyanadjan@yahoo.com (I. Djan)
}

\begin{abstract}
Received: October 20, 2018; Accepted: November 19, 2018; Published: December 31, 2018 To cite this article: Ismulyana Djan. Analysis of Balanced Scorecard Perspective in Private College Management as A Basic of Lecturer Performance Assesment (Case Study of Computer Science College of Binaniaga), The Management Journal of BINANIAGA, Vol. 03, No. 02, December 2018, pp. 71 - 80.
\end{abstract}

Abstract. The application of Balanced Score in a college institution especially lecturer performance is a new case, Computer Science College of Binaniaga is one that applies and utilizes this knowledge to develop strategic planning, implement and evaluate using balanced scorecard, the research is based on the implementation of the balanced scorecard theory developed by Kaplan and Norton through a case study at STIKOM Binaniaga college, the result of the study can illustrate that researchers can develop a strategy map and plan the balanced scorecard performance of STIKOM Binaniaga lecturers, where four balanced scorecard perspectives with several strategy targets at each perspective are measured by each strategy objective and target to be achieved will be easily implemented, this is to provide very clear information to the management of universities, that each perspective can be implemented well in accordance with the needs of colleges in terms of conducting performance appraisals of lecturers at Computer Science College of Binaniaga (STIKOM Binaniaga).

Keyword: Balanced Scorecard, Perspective

\section{PREFACE}

In order to realize the vision and mission of college institution, there are many techniques or methods in preparation of strategic plans that can be chosen as their basic preparation, including Space Matrix, Grand Strategy, TOWS Matrix, IE Matrix, BCG and Balance Scorecard. Certainly its application is very dynamic and adapted to field conditions and do not forget the competencies of stakeholders who will use it, considering that it is very tricky and complex about the comprehension that must be mastered before carrying out the strategic management analysis. The Balance Scorecard is one of the strategic management tools that might be considered the latest from other analysis tools, not to repeat the same mistakes, good at planning but difficult to implement, balance scorecard tries to focus more on real data that can be seen all the components involved in preparation and implementation, to the final phase before implemented, so that the gap between facts of institution and data written in a strategic plan has no significant difference, a strategic plan is a current data used as a basic for future implementation while current data is real data that is visible, detected, and can be accounted for by all interested parties at this time. Balance scorecard as stated by Robert S. Kaplan and David P. Norton "A set of measures that give top managers a fast but comprehensive view of business includes financial measures that tell the results of actions already taken complements financial measures with operational measures on customer satisfaction, 
internal processes, and innovation and improvement activities - operational measures that are the drivers of future financial performances.

If we find some definitions directed at business sector, it does not mean that nonbusiness is not relevant to use it, the usage of balance scorecard is important when nonbusiness sectors, including private universities want to get professional management and continue to develop in the future, then the balance scorecard can answer that. It is true that the point of all its goals is financial, but the important parts that support finance are those which are needed by private colleges to live today and in the future such as operational measures about stakeholder satisfaction, internal operation process, organizational innovation and enhancement of operational measure activation in order to control financial performance in the future.

Kaplan and Norton described about four perspectives of balance scorecard which can be a basic reference to implement and create the vision and mission of higher education as can be seen in figure 1:

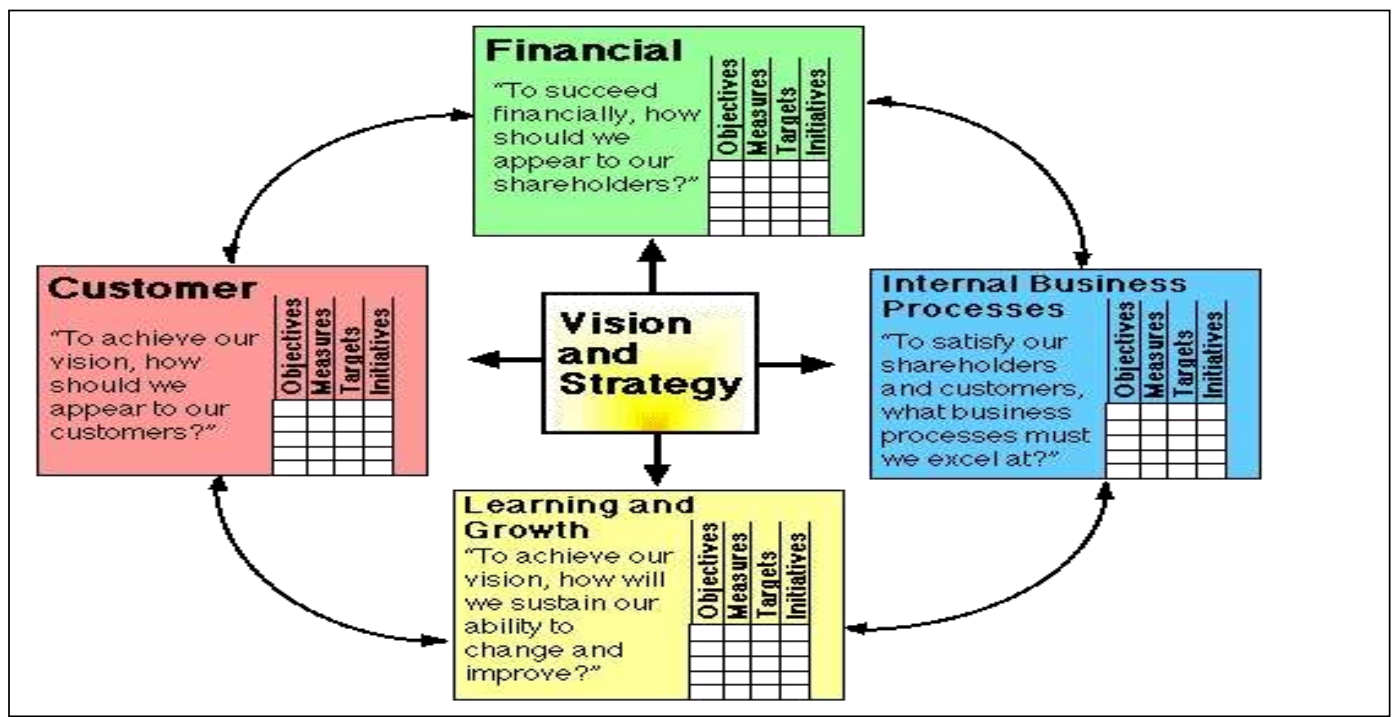

Figure 1: Balanced Scorecard

The balanced scorecard perspective is an integrated and interconnected process in order to create vision and mission of an organization through a confirmed planning strategy. Perspective learning and growth is the process of training education in order to improve employee performance. There are two things highlighted in this perspective, new employees training and they who do not understand and employees training in order to increase their competence while perspective internal business process is how the main activities of employees work optimally to achieve organization goals and to develope cooperation between lines, to utilize resources in the organization in order to achieve its goals, while the perspective of customers is to provide optimal satisfaction to those parties who have interest in the organization so that it can get feedback, not only financial value but more is customer satisfaction and to create customer loyalty and financial perspective emphasizes funding process for all activities, and considering that the organization as an object of research is non-profit, so in whole process of financial activity is only aimed in using budget process, and to create organization activities that lead to high efficiency level, to be able to compete with similar organizations, or other larger organizations.

Lecturer, the important pillar of private colleges, there are two categories of lecturer performance appraisal in their work activities, including permanent lecturers and non- 
permanent lecturers, permanent lecturers are full-time employees who work 6 up to 12 credits or equivalent 38 - 40 working hours or in accordance with applicable regulations, while non-permanent lecturers who work or teach in part time based on their confirmed time. Main task of lecturers is Tridharma of Higher Education, i.e. education, research, community service and other supporting sectors. Education is conducting teaching and learning activities or transfer of science, tutorials, testing and conducting education in a laboratory, field practice, guiding seminars and thesis, testing final examinations, guiding student activities, developing college programs, developing lecture materials, delivering scientific orations, and hold the position as head of higher education.

Whereas research is to produce a scientific work based on the results or published thoughts, to translate or transcribe scientific books, edit scientific works, make a patented plan, technological work and design, to make monumental arts and literary works. Community service is lecturer activities focus on education and research development. It provides training and counseling to the community, and other supports as the implementation of development and government tasks and also to conduct activities by unpublished writing about community. The last supporting sector activity for lecturers is an active lecturer of higher education committee or administration of government institutions, active in lecturer organizations, members of national delegations at international conference, active role in scientific conference, granted awards or certificates, carry out a supporting sector by writing a textbooks for high schools distributed nationally, granted an achievement in sport field or other humanity activities.

The balanced scorecard perspective is identic with business-oriented activities, it means that the main focus of activities always leads to profits, but Kaplan \& Norton's theory is more extensive. It can be implemented in all business-oriented and non-profit sectors. This research can be implemented in all types of balanced scorecard perspectives in order to create the performance assessment of lecturers specifically and integrated through strategy and concluded through organizational vision and mission. In this case, STIKOM Binaniaga specifically related with the main activities of permanent lecturers in this private college institution. We try to understand about the main activity of the lecturer in a college and how it relates to the balanced scorecard perspective and what strategic objectives should be the main focus of each lecturer in order to achieve the expected goals.

The purpose of this study is the implementation results of a strategy planning system including map strategy, balanced scorecard, action plan that is integrated with four balanced scorecard perspectives, including learning and growth, internal business processes, customer perspective and financial perspectives on lecturer performance of (STIKOM) Binaniaga. It is expected that the results of this system can be a bright spot in providing constructive and scientific input to the management of universities to provide input to lecturers, and at the same time to evaluate the performance of lecturers so that the quality of education, research and community service can be made by all lecturers.

\section{RESEARCH METHODOLOGY}

This research is qualitative in nature by applying one of the strategy methods developed by Robert S Kaplan and David P. Norton, i.e. Translating Strategy into Balaced Scorecard implementation to lecturer performance appraisals at STIKOM Binaniaga environment. Where the balanced scorecard has been accepted in all circles to measure performance, which is based on a previous strategic plan that can be applied in business or non-business activities, STIKOM Binaniaga utilizes this knowledge in longterm interests for STIKOM Binaniaga lecturers, as for the series steps as follows:

Step 1: Analyze vision and mission of STIKOM Binaniaga

Vision analysis, mission becomes important when all strategic planning activities must be directed towards the final goal to be achieved, so that 
strategy development can focus, so developing vision and mission that relevant with organization character is important.

Step 2 : Set goals, basic values, and basic confidence.

Step 3 : Arrange a strategy map, complete with strategy targets based on a perspective scorecard.

Step 4 : Set goals, based on each balanced scorecard perspectives.

Step 5 : Establish KPI (Key Performace Indicator) based on balanced scorecard perspective.

Step 6 : Set targets, based on the perspective of the balanced score card.

Step 7 : Arrange the action plan that has been compiled in the map strategy, based on the stated strategic objectives.

This study results are based on secondair data, in semester reports form, annual reports, student attendance, lecturer attendance, lecturer academic activities besides teaching, study program information, and other competent officials in organization such as vice chairman of academic staffs and other officials related to this study.

\section{RESULT AND DISCUSSION}

Binaniaga Computer Science College (STIKOM), as the object of this research has a vision statement that has been established and agreed, i.e. "Visi STIKOM Binaniaga." In 2025 it will become a prime computer science college at Information Technology field in West Java. "This vision is an achievement point for all academic and non-academic activities at STIKOM Binaniaga including lecturer academic activities. All lecturers of STIKOM Binaniaga as this research objects are 19 people, including 13 permanent lecturers of information system study program and 6 permanent lecturers of informatic engineering study program, they are obliged to carry out education, research, service activities community and other supporting activities.

Education as explained that lecturers are required to give lectures at least 14 up to 16 course meetings per semester, it means that if the lecturers of STIKOM Binaniaga are given tasks to teach two courses for 3 credits means that each lecturer will carry out 2 teaching activities fold, it means that their teaching activities is 6 credits, and 6 other credits can conduct research and community service as well as other supporting activities. It is related with the applicable provisions and the tasks to implement Tridharma higher education is a requirement for every permanent lecturer.

In order to rate lecturer performance, these activities must be reported in writing and contained in the system at STIKOM Binaniaga, including the presence of students and lecturers, midterm activities, final semester examinations, final grades of students issued by lecturers, seminars organized by institutions for lecturers, or seminars attended by non STIKOM Binaniaga lecturers, it must be reported in writing to the institution as well, also a research conducted by a lecturer, start from proposals preparation until research reports completed and scientific journals published must reported to the institution, including activities related to community service, it means that some of research resuts that have been carried out can be directly implemented in community. Lecturers can report non-academic activities as well that supporting factors apart from lecturer activities as education at STIKOM Binaniaga environment.

The purpose of Tridharma higher education, lecturer activities should focus on its vision that will be implemented by STIKOM Binaniaga, therefore in order to focus on vision, a strategy map must be prepared based on STIKOM lecturer performance balanced scorecard and planning for STIKOM Binaniaga, will explain in detail about the strategy objectives to be achieved based on the balanced scorecard perspective,

That strategy plan also related to balanced scorecard perspective including a strategy goal based on financial customer perspective, internal business processes, also learning and growth. Considering lecturer performance at STIKOM Binaniaga is not profit

Ismulyana Djan. Analysis of Balanced Scorecard Perspective in Private College Management as A Basic of Lecturer Performance Assesment (Case Study of 
oriented but the activities of Tridharma higher education institutions which funded by STIKOM global budget, financial perspective is not placed on customer perspective but equal between customer perspective and financial perspective. And each strategy goal will make its purpose, level of strategy target (Key Fermentance Indicator) and achievement targets at the end of the set period, in addition to the action plan or strategy initiative, the objective of this strategy is to be able to easily implemented at the level below and does not confuse all parts involved in implementing the balanced scorecard. Strategy map that has been compiled completely with strategy objectives based on perspective can be seen in figure 2 .

Learning and growth perspective is a perspective that needs our attention, it related to the effects because this perspective is the beginning of all balanced scorecard that we will compile. What needs our attention is the strategy target to be achieved, including high lecturer competence, lecturers who will teach must have a degree at least Strata 2 (S2) or master of education, and who have high GPA (Grade Point Average), pass the test and interview conducted by the elements of STIKOM Binaniaga leadership, their academic degree must be linear with the field of science they teach, until at the beginning of 2018, STIKOM Binaniaga has applied linearity of academic degrees with the required study programs, it means mostly lecturers are graduates of Information Study Program and Informatic System Engineering. Whereas the target of continuous quality of improvement implementation strategy is a management form conducted by the institution to give another image to the higher education management, it means that every step, every time, every academic or non-academic activity must be better changed. This control continues to become a routine job of internal quality assurance center of STIKOM Binaniaga. The success to manifest two strategy objectves of learning and growth perspective greatly influences the higher perspective, i.e. internal business processes.

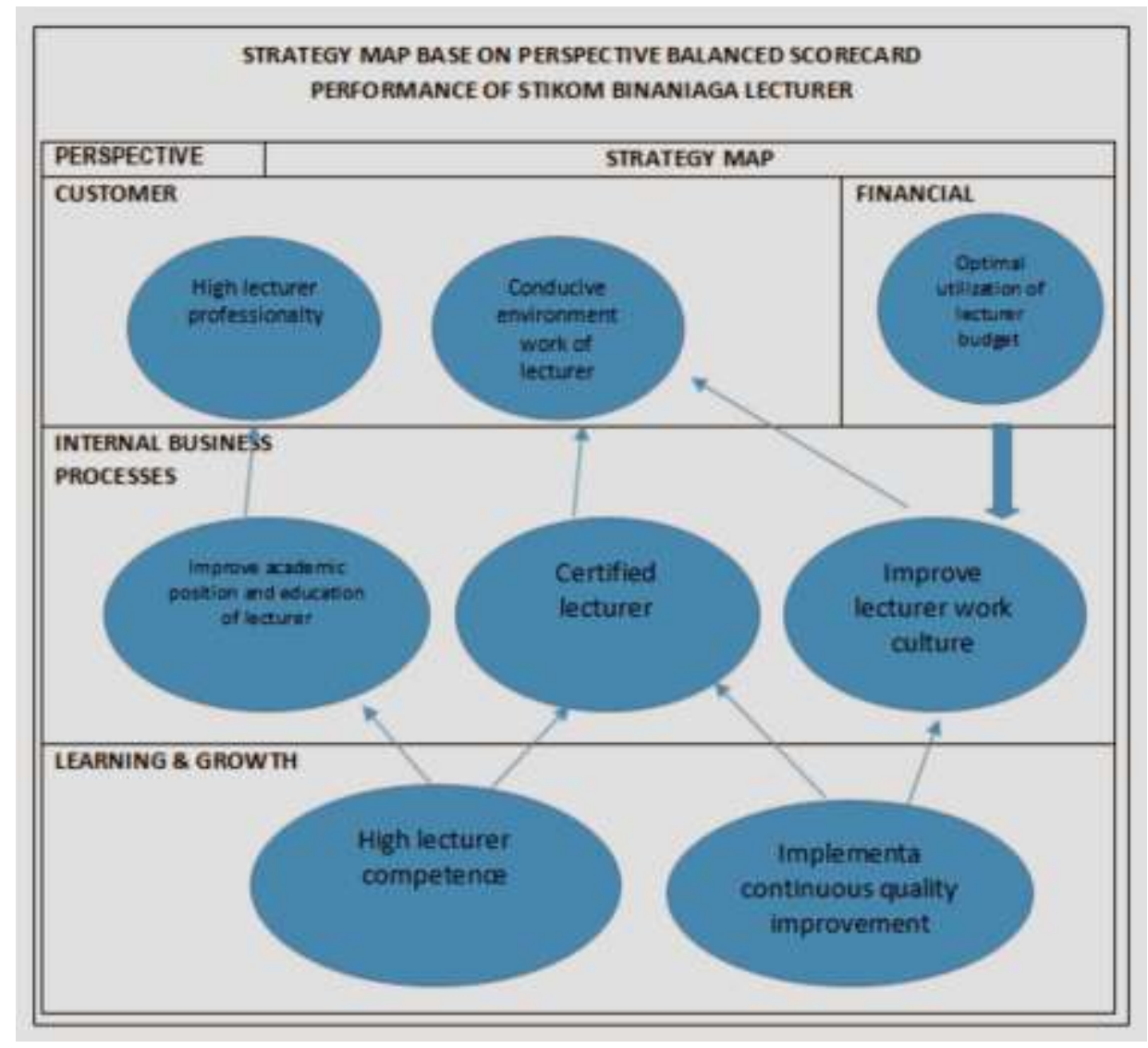

Figure 2: Strategy Map

Ismulyana Djan. Analysis of Balanced Scorecard Perspective in Private College Management as A Basic of Lecturer Performance Assesment (Case Study of Computer Science College of Binaniaga) 
There are three strategic objectives to be achieved in internal business processes perspective, the first is to increase academic position and lecturer education. The level of academic position starts with assistant experts, lecturers, chief lecturers and professors. STIKOM Binaniaga until this research conducted is able to increase academic position of lecturers by 6 people to become expert assistants. The academic position of lecturers, both expert assistants and professors is an accumulation of lecturer performance appraisal as a representation of Tridharma higher education activities. It means that the success of this strategy objectives is very determined by how many lecturers have academic position, and how much increases at each level in academic positions. Whereas lecturer education is a strategy objective to be realized, one year one lecturer in doctoral program (S3), besides lecturers are encouraged to often attend training held by LLDIKTI (Education Directorat General of Higher Education) or other external institutions which are well considered for the ability of lecturers development to understand their academic fields such as training or seminars organized by APTIKOM.

The second strategy objective in this perspective is the lecturer certification that is interpreted, government recognition in this case the Ministry of technology research and higher education (kemenristekdikti) towards lecturers who are declared professional lecturers in their fields, meaning that all lecturers in all regions of Indonesia have the right and obligation to obtaining the certification is said to be the ultimate goal of achieving a lecturer to get this recognition because there is an incentive in the form of a one-time allowance received by civil servants. Stikom Binaniaga as an institution that oversees lecturers must strive to make it happen and make the target of lecturer certification strategy an important thing to be realized for all STIKOM Binaniaga lecturers. While the third strategy target at the perspective of the internal business process that is built and is to be achieved is to improve the lecturers' work culture, this is a strategic target that is integrated with the strategy target of learning and growt, namely the implementation of continuous quality improvement, but must be able to create a working condition that continues to improve towards a better one as well, this culture is to anticipate the possibility of external influences on the internal environment in the STIKOM Binaniaga.

The customer perspective in strategy objectives preparation that would be achieved is high professionalism of lecturers, as described above that this strategy target is related with previous strategy objectives which is in learning and growth perspective and internal business processes perspective, high academic position with a high academic degree and lecturer certification, as well as high moral, dedication and loyalty supported with a conducive work culture environment, so the target strategy of high lecturer professionalism is expected to be able in implementation. The second strategy target in customer perspective is a conducive lecturer work environment, this strategy target is an effort by STIKOM to bring, implement, adjust and adhere to the values that apply in STIKOM Binaniaga environment to all lecturers, this is also to counter the possibility of the value of an outside party that is not in line or contradictory and is feared to affect the work culture in this institution.

At the financial perspective, the strategy target to be implemented is the optimal utilization of the lecturer budget, as explained above that the amount of the lecturer budget has been implemented by Binaniaga foundation as STIKOM organizing committee, this budget is submitted by the institution to obtain approval and implemented in accordance with the schedule of lecturer activities Tridharma of higher education. There are two budget strategies to be achieved. The first is how budget discipline towards the agreed programs can be implemented and the second is to optimize the efficiency of budget and effectiveness of programs as institution priority. 


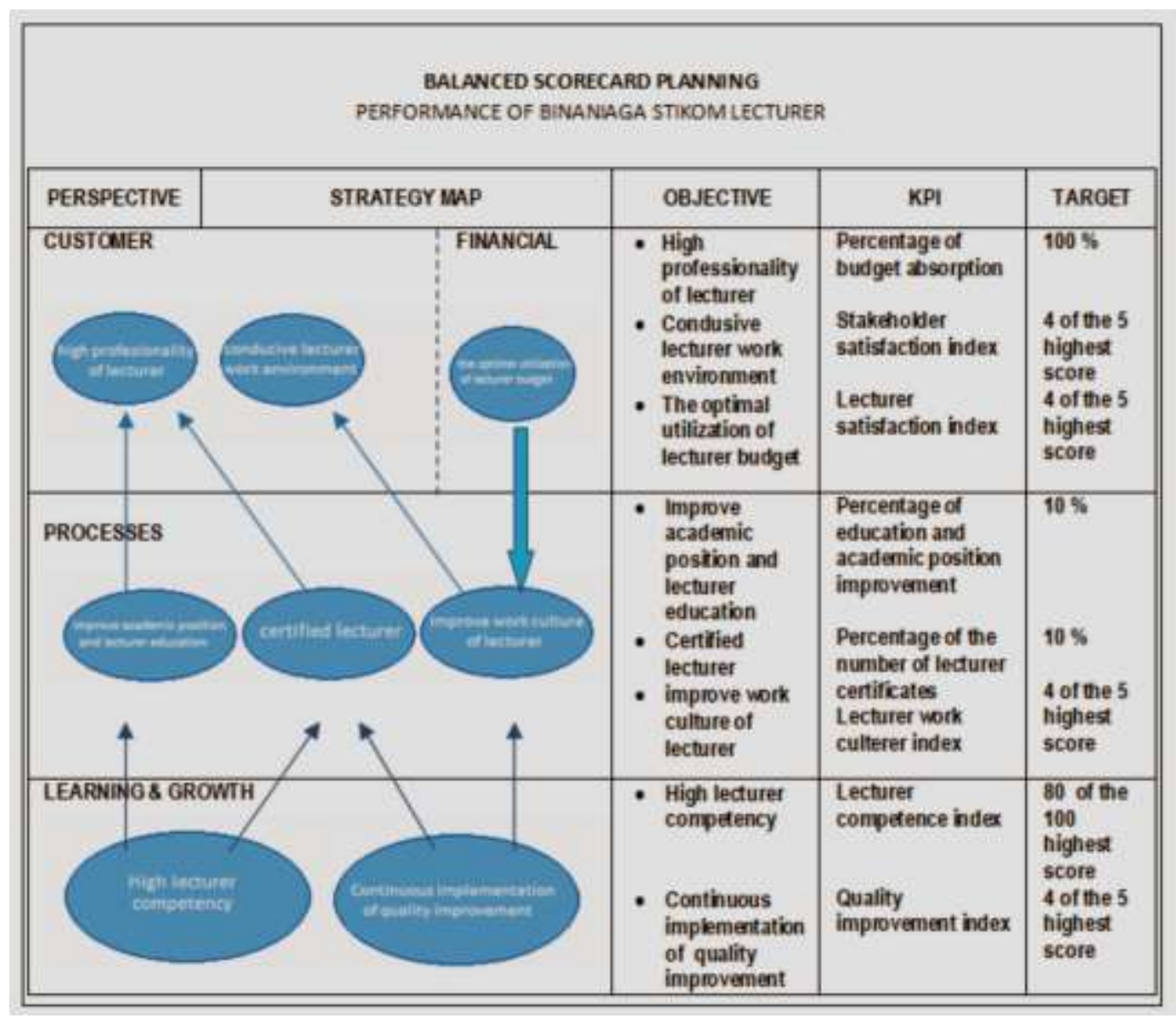

Figure3: Balanced Scorecard Planning

After setting a complete strategy map with strategy objectives based on four balanced scorecard perspectives the next step is to complete the strategy objectives with the objectives to be achieved, level of each strategy or KPI objective, and the achievement targets of each Key Performace Incidator (KPI). It can be seen in FIGURE 3. The objective of utilizing optimal lecturer budget at perspective financial, provides an applicative understanding that the level of success set by STIKOM college management is the amount of budget absorption that has been determined which means that it is very good to get the absorption rate close to $100 \%$, which is followed by budget discipline based on priority programs that are found together with all management of higher education including Binaniaga foundation and genuine efforts to make efficiency. Whereas the lecturer professionalism is high, measured by Key Performance Index with stakeholder satisfaction index, it means that the higher professional level of the lecturer, the higher the index level is obtained, this index is the perception of all stakeholders with STIKOM Binaniaga especially those with an interest in lecturers, such as students, head of study program, leadership element, and all staffs at STIKOM Binaniaga. And the objective of a conducive lecturer working environment is measured by KPI lecturer satisfaction index, it means that the lecturer satisfaction level is better for his work environment. Then the lecturer perspective will get higher level of lecturer satisfaction index that he gives.

The final objective of internal business processes perspective on lecturer performance appraisal, there are three objectives; increasing academic position and lecturer education, the measure determined in its achievement is the percentage level of increase in lecturer functional position and lecturer education, the percentage of STIKOM lecturer certificates increase by $10 \%$ every year. And the second objective is certified 
lecturers, where the measure used for the achievement of this goal is the number of lecturer certificates increasing by $10 \%$ every year, and in certain years it is expected that mostly STIKOM Binaniaga lecturers have a lecturer certificate. And the third objective in the internal business processes perspective is to improve lecturer work culture, the measure used is based on lecturer work culture index, which uses the highest scale 5 and 1 the lowest, and goal achievement at the end of the year is a score 4 from 5 the highest.

Learning and growth perspective has final goals, the first is high teacher competence, it has been carried out by STIKOM Binaniaga to get qualified lecturers who have high dedication, loyalty and morality, at this perspective, strategy goal setting or final goal that is to be achieved is very decisive for success at the next perspective therefore to realize the lecturers expected by the institution, it is necessary to pay attention to the lecturer competence, the measure determined is to use lecturer competence index, when recruitment, education and training and lecturer placement are based on good scores, the institution sets a score of 80 from 100 the highest. And the second from this perspective with the objective of continuous quality improvement implementation, can be measured by the quality improvement index key performance indicator, expected at the end of each period to get a score of 4 from 5 the highest.

\section{CONCLUSIONS AND RECOMMENDATIONS}

Balanced Scorecard is a strategy performane management tool that gets attention among observers of strategy policy and good strategy researchers specializing in profit oriented and non profit companies, one of them is STIKOM Binaniaga as non-profit oriented, the application of balanced scorecard becomes interesting and difficult in interpreting some terms of balanced scorecard but along with the time and experience of the researcher, these difficulties can be overcome, from four perspectives in the balanced scorecard, financial perspective, customer perspective, internal business processes perspective, and learning and growth perspective, only the financial perspective that looks different in the picture and strategy map, seen linear to customer perspective, it shows that the lecturer performance appraisal based on the balanced scorecard is only one unit part of balanced score as a whole or Suwardi wrote in his book "Step-by-Step Balanced Scorecard" tells about the cascading process, so the assessment of financial perspective lecturers' performance is only the process of implementing cost and efficiency budgets, does not produce separate profit or finance, so the main focus of balanced scorecard process is lecturing, the target strategy that is built on the other perspective is directed at achieving results on customer perspective.

To perfect the application of a complete and integrated balanced scorecard in all sectors at STIKOM Binaniaga including the need for a systematic link with the internal quality assurance center unit and the smallest part below, there needs to be in-depth study to follow-up this research, because there are still many lack of good data, and difficulties in implementation in the field, the researcher recommends that the continued research is carried out in a comprehensive and detailed manner, whereas this research can be used as a good data base or basic to be developed as an improvement research.

\section{REFERENCES}

David, Fred R., Strategic Management Concepts and Cases, New Jersey: Pearson Education Inc. Upper Saddle River, 2006.

Hunger, J. David, Thomas L. Wheelen, Strategic Management, Wesley Publishing Company. Inc. 1996.

Ismulyana Djan. Analysis of Balanced Scorecard Perspective in Private College Management as A Basic of Lecturer Performance Assesment (Case Study of 
Kaplan, Robert S., David P. Norton. Translating Strategy into Action the Balanced Scorecard. Library of Congress Cataloging in Publication Data .1996.

Luis, Suwardi, Prima A. Biromo. Step by Step in Cascading BALANCED SCORECARD to Functional Scorecard. Penerbit PT Gramedia Pustaka Utama, Jakarta 2007.

Yuwono, Sony, Edy Sukarno and Muhamad Ichsan. Petunjuk Praktis Penyusunan BALACED SCORECARD Menuju Organisasi yang Berfokus pada Strategy. Penerbit PT Gramedia Pustaka Utama, Jakarta 2002. 
The Management Journal of BINANIAGA Vol. 03, No. 02, December 2018 PISSN: $2527-4317$

EISSN: $2580-149 x$

This page intentionally be emptied.

Ismulyana Djan. Analysis of Balanced Scorecard Perspective in Private College Management as A Basic of Lecturer Performance Assesment (Case Study of Page : 80 Computer Science College of Binaniaga) 